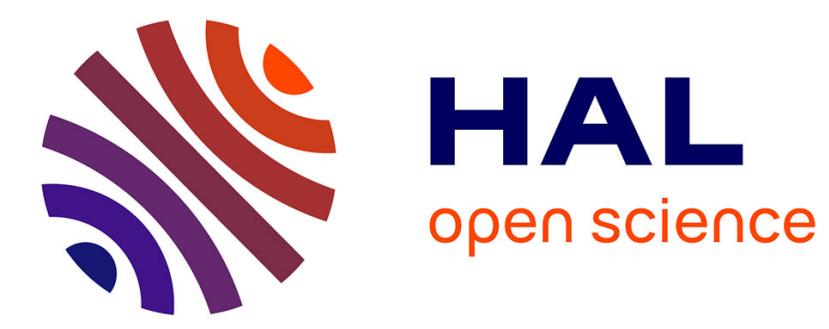

\title{
The Discursive Effects of the Haiku-based SADUPA Poetry Technique in Palliative Care
}

Alfonso Santarpia, Eric Dudoit, Melanie Paul

\section{To cite this version:}

Alfonso Santarpia, Eric Dudoit, Melanie Paul. The Discursive Effects of the Haiku-based SADUPA Poetry Technique in Palliative Care. Journal of Poetry Therapy, 2015, 28 (3), pp.174-194. 10.1080/08893675.2015.1051288 . hal-01180712

\section{HAL Id: hal-01180712 \\ https://hal-amu.archives-ouvertes.fr/hal-01180712}

Submitted on 28 Jul 2015

HAL is a multi-disciplinary open access archive for the deposit and dissemination of scientific research documents, whether they are published or not. The documents may come from teaching and research institutions in France or abroad, or from public or private research centers.
L'archive ouverte pluridisciplinaire HAL, est destinée au dépôt et à la diffusion de documents scientifiques de niveau recherche, publiés ou non, émanant des établissements d'enseignement et de recherche français ou étrangers, des laboratoires publics ou privés. 
Citation : Santarpia, A., Dudoit, E., \& Paul, M. (2015). The Discursive Effects of the Haiku-based SADUPA Poetry Technique in Palliative Care. The Journal of Poetry Therapy, 28(3), 1-15.

DOI: $10.1080 / 08893675.2015 .1051288$

The Discursive Effects of the Haiku-based SADUPA Poetry

Technique in Palliative Care

Santarpia Alfonso 1,

1. Aix Marseille Université, LPCLS EA 3278, 13621, Aix en Provence, France.

Dudoit Eric 2,

2 Medical Oncology Unit, La Timone Hospital, AP-HM, Timone, F-13385 Marseille, France.

Paul Melanie 1

1. Aix Marseille Université, LPCLS EA 3278, 13621, Aix en Provence, France. 


\begin{abstract}
This qualitative study seeks to present the discursive effects of SADUPA, a new poetry-based technique centered on haiku, in the context of psycho-oncological treatment. The technique is used with a terminal cancer patient, Mr. A. The psychological processes involved with and the poetic writings arising from the technique are discussed. In particular, the discursive variations in Mr. A's narrative of his illness are described as they occurred before and after his poetry writing. The authors suggest that writing workshops based on the brief poetic structures of the haiku can enable patients to produce a larger and more singular narrative about their end-of- life experiences.
\end{abstract}

Keywords: haiku, SADUPA, poetry therapy, software TROPES V.8.4, discourse analysis, cancer, palliative care. 


\section{INTRODUCTION}

Patients who receive palliative care in psycho-oncological contexts face a dramatic paradox: while treatment seems able to eliminate pain fully, there is a heightened experience of finitude and of the impending ultimate separation (Bounon \& Lassaunière, 1990). In a recent qualitative study, Semino, Demjen and Koller (2014) found that the members of the sample of thirteen hospice managers distinguished clearly between "good" and "bad" deaths in their narratives about the end of life. Stolberg (2014) found that metaphors of war were frequently used to describe cancer in early modern Europe, with references to armies of hostile cells attacking the body and needing to be fought off. Jasen (2009) spoke of cancer as a "silent killer." Menzel (1954) also investigated metaphorical representations (Murphy, 1996) and patients' actual experiences; he was one of the first to depict cancer as a battle or as a war in which cancer cells attack the body. As Southall (2013) noted, patients receiving palliative care tend to evoke themes related to war and to journeying when speaking in a more general sense of their end-of-life experiences. These themes illustrate the rhetorical forms patients use to conceptualize and represent their personal experiences of illness (Pedinielli, 1993, 1999). Southall's more recent review of literature, which examined the types of communication used by patients in palliative care, highlighted the critical role of metaphor in establishing the therapeutic relationship between patients and their psychologists and doctors. As he noted, the use of metaphor to express and conceive of experience is particularly helpful in allowing the patients to interpret and to articulate in depth the experience of death and dying. As Santarpia, Tellène, and Carrier (2013) have shown, patients' experiences can be conveyed in metaphors and imagery of varying degrees of complexity; for example, a patent who had experienced a total mastectomy described herself as an "extra-terrestrial" (p. 160). Cannone, Marie and Dudoit (2008) presented another example of figurative language used by a late-stage breast cancer patient: 
They took my heart when they took my breast, they took everything.... I am dirty, my insides are rotten, I want to scrub and scrub myself with bleach to get rid of this filth, take out my organs and put them back when they are clean, wash away the dark blood, do you think that's possible?... Of course I know it isn't... I wish I could fly away like a bird, be free, I would be a raven.... (p. 191)

This narrative includes imagery of a "dirty body," "dark blood," and a sort of "containing body" from which things can be taken out and put back in. Psychological work aimed at transforming the cancer patient's anxiety-ridden experiences by means of new metaphors and creative imagery can bring new therapeutic horizons to psycho-oncological treatment.

Poetry, a literary form that privileges figurative language, is very well suited to this kind of transformative work. Poetry therapy is a technique that explores the effects of poetic writing on psychological processes from a multidisciplinary point of view (Mazza, 1996, 1999). The field has already developed a significant literature (Blanton, 1960; Leedy, 1969; Prescott, 1922; Shrodes, 1949) and features an international peer-reviewed publication, The Journal of Poetry Therapy. Poetry therapy shows how working with poetic forms can help patients deal with the drastic life changes that accompany serious medical conditions and illness. It has been recognized in the psychiatric (Houlding \& Holland, 1988; Langosch, 1987; Shelton, 1999) and psychotherapeutic (McLoughlin, 2000) literatures. Recent studies have examined the role of poetry and metaphorical representation (Gibbs, 1994; Lakoff \& Johnson, 1980, 1999; Lakoff \& Turner, 1989; Turner, 1998) in Freudian psychoanalysis and in psychiatry (Santarpia, Blanchet, Venturini, Cavallo, \& Reynaud, 2006; Santarpia, Venturini, Blanchet, \& Cavallo, 2012). In psycho-oncology, the SANTEL technique, in which Baudelaire's poetry is used to help breast cancer patients reconfigure the erotic body image, has been developed by Santarpia, Tellène and Carrier (2013). Mazza and Reiter 
(1997) have each taken a theoretical approach and have identified the therapeutic processes specific to poetry therapy:

- Expressing oneself, enhancing creativity (having new ideas, insights and information), increasing self-esteem;

- Symbolizing experience with metaphor and narrative;

- Encouraging concrete thinking and problem-solving;

- Improving communication skills through a more figurative use of language.

Others have identified additional aspects that are often in play: finding lost and forgotten psychic objects (Clancier, 2001); outlining and synthesizing the productive imagination (Ricœur, 1982); stimulating the imagination and developing awareness of harmony, symmetry and aesthetics in general (Gergen, 2000).

These therapeutic characteristics are typical of both humanist (Maslow, 1943, 1962) and newer cognitivist (Collins, Furman, \& Langer, 2006) approaches to psychotherapy. Poetry work has the potential to go further than techniques that focus only on expression of emotion or catharsis. Of particular interest to the present authors is the possible use of a specific poetic form, the haiku, in psycho-oncology, especially in response to the emotional drama of palliative care. Haiku, with its capacity to express lived experience, has already been used both in therapeutic work with schizophrenic patients (Collins et al., 2006) and as a pedagogical tool in the neurosciences (Pollack \& Korol, 2013). A haiku is a very short form of Japanese poetry written in three phrases, each of which traditionally has a set number of syllables: a short phrase of five syllables followed by a long phrase of seven syllables and then another short phrase of five syllables. While haiku usually include a word that ties the poem to the real world and, in general, to nature, this aspect can be absent in what are known as "free" haiku. Haiku contain a caesura, or cutting, which punctuates the movement from one image to another. Unlike waka and tanka, other traditional forms of Japanese poetry, 
haiku are not sung. They try to express the evanescence of the world and things, contain a reference to the seasons and include a caesura that divides the verse into several parts. Otherwise, such a poem would be a free haiku or moki. A person who writes haiku is called a haiku poet or haijin.

One of the best-known Japanese haiku was written by Basho Matsuo:

The old pond;

a frog jumps in -

the sound of the water

Basho Matsuo (Translated by Aitken, 1978, p. 25)

\section{RESEARCH OBJECTIVE}

The authors will describe the discursive effects of a specific poetry-writing technique based on the haiku: the SADUPA technique (this name is composed of the first two letters of the last names of its three authors). It was developed by our team specifically for use in the context of palliative care. We will describe the psychological processes involved with and the type of poetic writing arising from the use of haiku with a terminal-phase cancer patient, whom we will call Mr. A. Specifically, we will try to describe the discursive variations in this patient's narrative of his illness before and after working with him on writing haiku.

\section{METHODOLOGY}

Presentation of the Case and of the Patient's Consent

This case study was conducted in a French oncology unit by a training psychologist. The patient, Mr. A, was a male, age 70, widowed with two daughters, who had retired from the French national education system. He had a malignant tumor of the thigh, which had metastasized to his lungs; the cancer was in terminal phase and, sadly, the patient died a few months after his participation in this study. The training psychologist asked the patient if he would be interested in doing some poetry writing and he accepted. He signed a consent to 
participate form in which it was specified that he could leave the study at any time and that all personal information about him would be kept strictly confidential. Psychiatric evaluation indicated that Mr. A was experiencing a major depressive episode, and this diagnosis was confirmed by the training psychologist's observations. This condition prevented Mr. A from engaging fully in intellectual activities, something particularly difficult for a person who loved reading, writing and history as much as he did. He had started to avoid going out, passing his time in trying to sleep, so as not to think about his illness. He turned away visitors and refused invitations. His hospitalization allowed him to throw himself into a writing project in which he spoke of his feelings, his life experiences and in particular the good times spent with his wife, his fears and his coming death. He devoted a good deal of time to his poetry work because he wanted to express himself as fully and authentically as possible. This work made it easier for him to communicate with the training psychologist, for the haiku allowed him to grasp what was happening within him and thereby to confront his illness.

He was always very happy to see the training psychologist and he became much more animated while he was discussing the historical events that intrigued him: he was more expressive, spoke more loudly, sat up in bed, acted out his stories and would even break into bouts of laughter. It became a sort of routine; each time they met, Mr. A would tell an historical anecdote about, for example, Napoleon's life or the beginnings of democracy. As a former high school teacher, he took great pleasure in this. It became a means of communication, for he would often come back to his anecdotes, especially when he had nothing more to say about himself or his poetry. He also had a quite singular experience of nature, and this would come up frequently in the interviews and sessions. Before he became ill, he enjoyed taking walks in the forest, where he would breathe in the fresh air to revitalize himself and rid himself of his problems, look at the landscape and especially at the sunsets, which brought him a sense of well-being. Mr. A said that he could wait for hours for 
nightfall. His illness led him to stay in a convalescent center on the seaside, but he was so sick that he could only contemplate the sea from the other side of the window, refusing to go out.

The project of holding a poetry-writing workshop was presented to the nurses, psychologists and physicians of the oncology unit by the training psychologist who, in something of a departure for French cancer treatment, explained the complexity of different writing strategies (see "Design and Procedure" below) to the health care professionals. The project was accepted with curiosity and interest. All the interviews were conducted in French; they were recorded with a dictating machine and then transcribed. This article and the haiku were then translated by a professional translator whose native language is English.

Design and Procedure

We established a four-phase poetry writing technique, which would take place over four to six weeks, depending on patient health.

1. A preliminary interview was conducted in which several existential themes were discussed: Body, Illness, Family and Creativity. This "semi-directive" interview model, inspired by Blanchet's (1991) approach, involves three types of follow-up: questioning, statement and reiteration. This was used to make a connection with participants, as well as to collect samples of how they spoke about their illnesses and to see how open they were to undertaking the creative work of poetry writing.

2. In the second phase, fifteen haiku written by important Japanese poets and taken from collections of haiku available on several French websites (for example, Irubetagoyena, 2010; Marchand, 2014; Moysan, 2012) were presented to each participant (see Appendix A). Three haiku were chosen for each of the following five existential themes: Death/Aging, Love, Spirituality, Time and Sensations. After a discussion first among the authors themselves and then with members of their research team, these 
themes were selected for their ability to inspire deep reflection on the end-of-life experience. All fifteen haiku were read to the participant by the training psychologist. After this, they were read again, and the middle line of each was omitted. The participants were then asked to fill in the missing middle lines of the haiku in order to give them a personal meaning (see the examples in Appendix B). Next, the training psychologist read the haiku with the newly added lines aloud to the participant, to help establish their working alliance.

3. During the third phase, patients presented a poem composed of several haiku, which they had been asked to write on their own, whether at home or in the hospital. The poem was read aloud to the training psychologist.

4. Lastly, a final interview was conducted, again using Blanchet's semi-directive model with three types of follow-up: questioning, statement and reiteration. The themes of Body, Illness, Family and Creativity were again addressed, after the poetry-writing experience.

\section{The Work of Poetic Writing}

In Table 1, the center column presents one example of the participants' work of poetic learning. Here Mr. A filled in the missing line with his own poetry.

\begin{tabular}{|c|c|c|}
\hline Line 1 & Patient Mr. A & Line 3 \\
\hline To read in the lake & is to seek to interpret & ripples on water \\
\hline And so I am here & the nostalgia of passed time & is without limit \\
\hline Hawthorne now in bloom & the springtime which now returns & and I, growing old... \\
\hline Crossing the wastelands & all of my memories & weigh down upon me \\
\hline As we grow older - & and each of our weaknesses & is a source of tears \\
\hline In the young grasses & the old man lying stretched out & forgets his roots. \\
\hline All in this world & would become more beautiful & to consider the flowers! \\
\hline Beat of butterfly wings & it's the lightness and color & of this world \\
\hline Our beautiful years & were so very happy & sunshine in July \\
\hline Morning in spring - - & radiant and murmuring & is brimming with life! \\
\hline For that very look & I agreed to dive headfirst & into all of hell's fires \\
\hline Nothing that is mine & but my thought, the bygone days, & and the cool, fresh air \\
\hline Time which effaces nothing & is a very strong cement & for intense loves \\
\hline A carp jumps - & and revives all of his life & in the autumn moon \\
\hline Your arms, I forget & in your arms that I am & amnesiac love \\
\hline
\end{tabular}


Table 1. The phrases provided by Mr. A (in italics) when he was asked to fill in the missing line of the haiku.

After this work of learning the haiku technique, participants were asked to write a free Haiku.

Mr. A's Free Haiku (Appendix C, from Phase 3: Original Writing)

The hundred-year-old olive tree before me

Unfurls its branches and its hues

Ifeel, standing there, my ephemeral existence

When my cat on my lap lets go and purrs

I feel that he is so trusting, happy

That my own soul is calmed

The scent of fresh-cut grass,

Is the spring which returns

And the time which each year has passed is forgotten.

\section{Discursive Analysis of the Text}

Discourse analysis of the preliminary and the final interviews was provided by version 8.4 of the French edition of the Tropes semantic analysis software program (Molette \& Landré, 2014), which was employed to examine the discursive categories used by the patient. This program produces a quantitative analysis of a text (interview transcription, clinical notes, free writing, etc.) by breaking it down into different categories defined by the terms used by the text's author (nouns, verbs, adjectives, etc.). A personalized semantic network or "Scenario" can also be defined by the analyst and added to the specific discursive corpus. 


\section{RESULTS}

We will first present the nouns (such as "illness" and "cancer"), adjectives, verbs and pronouns used by Mr. A during the preliminary and final interviews, in order to illustrate his experiences stemming from writing haiku.

Mr. A’s Semantic Network

The Tropes program identified the following quantitative characteristics of the corpus: 407 nouns with each noun category occurring 2 times on average; 266 verbs with each verb category occurring 5 times on average; 122 adjectives with each adjective category occurring 2 times on average.

In order to analyze the theme of illness, we used Tropes to select the following target terms ${ }^{1}$ (presented here with the number of occurrences of each in parentheses): Body (10), Branch (4), Cat (10), Dog (9), Lamartine (3), Nature (4), Olive tree (4), Operation (5), Passion (4), Pleasure (8), Sensation (3), Shipwreck (3), Sick [person] (3), Solitude (1), Spring [season] (5), Time (10), To get upset (3), To calm/soothe (3), To imagine (3), To laugh, nonverbal (18), To look at (9), To purr (4), To write (15), Alone (7), Amusing (2), Beautiful (6), Cyclical (5), Cynical (2), Different (5), Difficult (3), Ephemeral (1), Eternal (2), Fatal (1), Immortal (1), Life (11), Linear (2), Living (2), Negative (3), Sad (3), Strong (3), Thick (2), Unhappy (1), Wonderful (5).

Comparison of Word Categories Used in the Preliminary and Final Interviews

The following bar graphs show the discourse analysis results for target terms (Figure 1) and personal pronouns (Figure 2) as these were used by Mr. A in the preliminary and final interviews.

1 Nouns are written in singular form, but Tropes 8.4 categorizes and counts plural forms with the singular form. Verbs are written as infinitives, but all forms and conjugations are categorized and counted with the infinitive form. Likewise, all forms of French adjectives (masculine/feminine, singular/plural) are categorized together. 


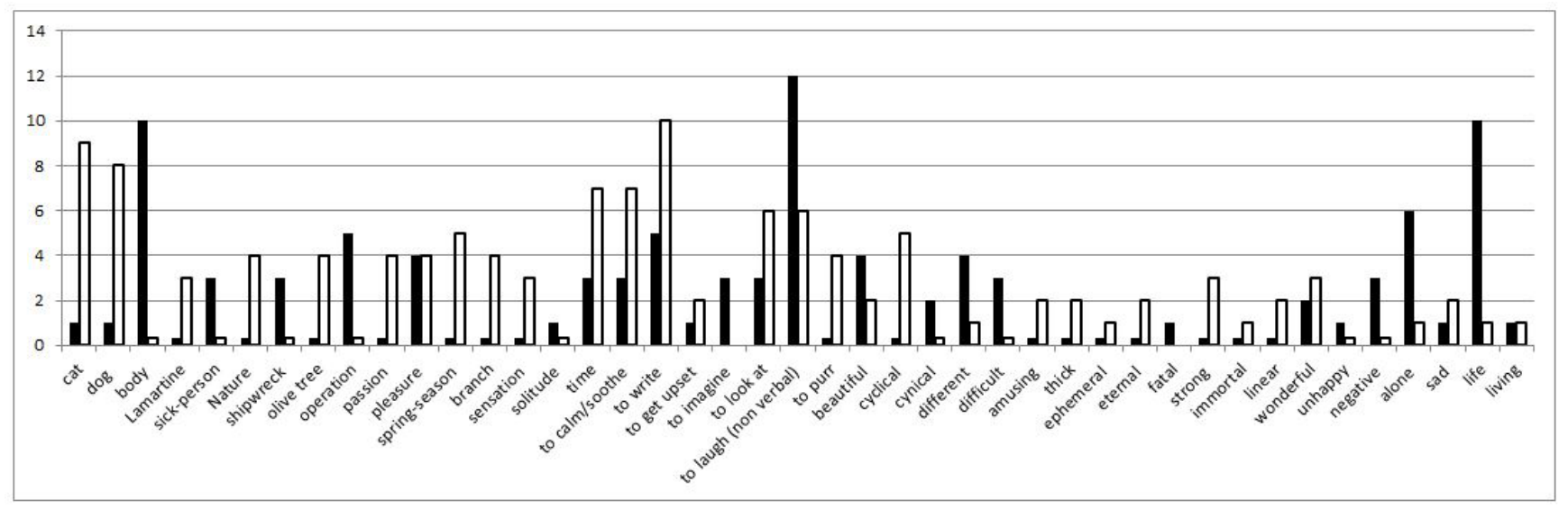

Figure 1. Target terms used by Mr. A. The black columns indicate the number of target terms appearing in the preliminary interview, and the white columns indicate the number of target terms appearing in the final interview.

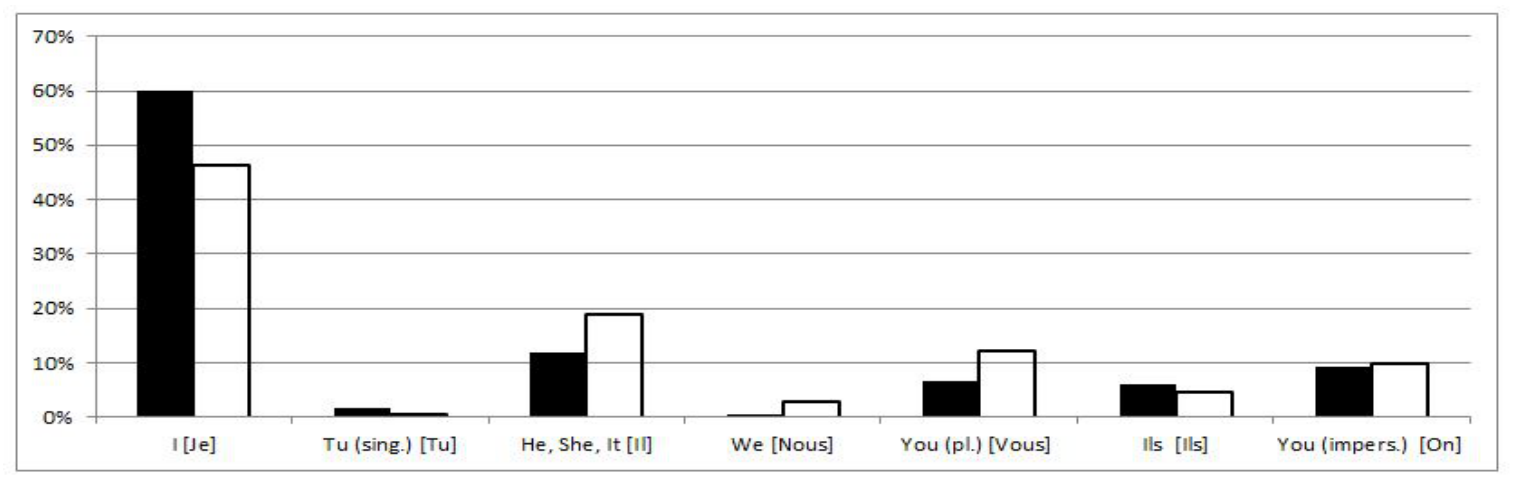

Figure 2. Personal pronouns used by Mr. A. The black columns indicate the number of personal pronouns appearing in the preliminary interview, and the white columns indicate the number of personal pronouns appearing in the final interview.

The Narrative of Illness in the Preliminary Interview: Excerpts from the Transcript of Mr. A's speech ${ }^{2}$

a) The bitter laughter of "being in parentheses"

“I'm in parentheses. And I've been cut off from others. Because I can't, look I'm stuck. That quadriceps muscle won't move. I can't get dressed by myself: no, not

2 Target terms identified by Tropes appear in bold. 
for that, she tries not to hurt me. (He laughs, holding out his hands and looking at them). (He laughs.) Well, because I think I do have big hands.”

b) Getting sick is like a shipwreck you have to get beyond

"I remember how De Gaulle said that old age was a shipwreck. Deep down, I tell myself that it's not just old age that is a shipwreck. It's the illness, too. Because what's happened to me here, that's a shipwreck. And there is this part of being sick where there is all of this doubt. You have to [Il faut $]$ get beyond that."

c) Getting the diagnosis and the drama of accepting it

"Well, when I found out, I told myself: life ends here. Let me tell you, it's... I found out at the end of March and I was operated on at the end of June. It was awful and even now I still tell myself that that was really a fatal blow. I just can't imagine it and what's more the psychologist told me - and I think he's right about this - that you always have to [il faut toujours] give your inner child the reassurance it needs. I told him I would try... yes, I told myself that there isn't any time left. The curtain has dropped. It's very hard. So I try to tell myself that the show will go on. But deep down, I don't believe it. I try to persuade myself without really believing. I act cynical, I bring up things that I really shouldn't.”

d) The paradox of solitude and being with pets

"Right there is the whole paradox, because I love being around people but I love having moments when I can be alone. Moments when I can be with myself, catch up with myself, get my energy back. But alone with company: with a cat or a dog. I'm alone but with an animal companion. We're never alone in life." 
The Narrative of Illness in the Final Interview: Excerpts from the Transcript of Mr. A's speech

e) Deepening of the writing work and signs of depression

"Nature is cyclical, we are linear. That's what is odd, yes but I don't like them. I have the impression that I can't find the right words to express what I really feel. I write, but what I feel, I feel it more strongly than I what I've written."

f) The sad, complex metaphor of the olive tree and the unexpected mention of Lamartine

"Yes, with this olive tree which is a hundred years old - actually, people [on] say that it is immortal, yes because the green coloring is so beautiful. The different shades of green, the twisted limbs with their small branches. Yes, in reading this haiku I remembered a poem by Lamartine who said: time has no shore, time has no harbor, it flows and we go on. That has always stayed with me, you are very nice. I don't know if I can change anything but I would like to find words that are strong enough to describe what I saw in the olive tree. Because the branches and the color are really not enough to describe it. There is something else, you know that its trunk was twisted, with some thin branches and others that were thick: that's it, although I did hesitate a little. I told myself that with the word "branch" it was possible to see that [on voit bien]. Yes, I would say that nature is eternal and people pass. I tell you that time has no shore, time has no harbor, it flows and we go on. You see, it just came back to me when I was reading, I was thinking of it when I wrote that. I really have no idea where those two lines from Lamartine came from." 
g) The gentle cat and being soothed

"Then the second is when my cat just lets go and purrs while sitting on my lap, I can feel that he is happy, secure and well, and then I calm down too. The cat soothes me. He's like me, he purrs and it is this letting go and trust. Because you still remember that it's a cat and any moment he can start clawing you. But he looks at you and lets go and so do we. I can't express the letting go and the pleasure any better than that. Dogs are not the same - the dog follows you around wherever you go. Dogs are more direct. Cats are sweet, oh yes, it was my wife who got me to love cats. I didn't really like them much at first. Cats would never come over to me. But as soon as they could feel my affection for them, that I was comfortable with them, it was incredible. They'd be all over me. Yes, I've missed them."

h) Awakening of the senses and the time of the seasons

"It's true that the scent of cut grass is spring for me. It smells so good, yes, that's right. And something good I'm thinking about now is when the nightingales start to sing in the evening. They sing and their song is wonderful. All you need to do is whistle a little and they answer you. So, there used to be more and more nightingales. It's the same as the cicadas, there are fewer of them than before. We're cutting down [On coupe] the pine trees too, that might be why, yes, spring is pleasant. See, winter is pleasant too with its colors but it doesn't feel the same [on n'a pas les mêmes sentiments]. Spring makes you [on] want to get outdoors but in winter you want to stay inside. Nature gives you [on] huge sensations. Without even moving around, just by observing it. It's one of the best things a person can do when they are feeling down. Find a spot and stand still." 


\section{DISCUSSION AND CONCLUSION}

In keeping with the literature on the effects of poetry therapy, it was to be expected that Mr. A's discourse would change over the course of the study. Our results describe the discursive variations in Mr. A's narrative of his illness before and after his work on haiku writing. We observe overall that, from a quantitative perspective, Mr. A no longer referred in the final interview to terms such as "body" and "shipwreck" ( 0 occurrences in the final interview) which he had used in the preliminary interview. He also relied less on a defensive process such as the non-verbal effort to "laugh" about his condition (6 occurrences in the final interview as compared with 12 in the preliminary interview). Lastly, his discourse in the final interview included a new metaphor, that of the "hundred-year-old olive tree," which was accompanied by a somewhat depressive reflection on time and existence. The reduction (from $60 \%$ in the preliminary interview to $44 \%$ in the final interview) in the use of the firstperson pronoun, which indicates the patient's involvement in his own discourse, could suggest that the self had become more open to others.

From a more qualitative perspective, the authors would like to highlight the expressive effect (Mazza, 1999) that poetic writing can have as regards frustration and the impossibility of expressing experience in writing; for example, Mr. A stated: "I have the impression that I can't find the right words to express what I really feel. I write, but what I feel, I feel it more strongly than what I've written." It is similarly interesting to note the effect of metaphorical symbolization (see Mazza, 1999, p. 4) in the new metaphor of the "hundred-year-old olive tree": "Yes, with this olive tree which is a hundred years oldactually, people [on] say that it is immortal, yes because the green coloring is so beautiful. The different shades of green, the twisted limbs with their small branches. Yes, in reading this haiku I remembered a poem by Lamartine who said: time has no shore, time has no 
harbor, it flows and we go on." This last sentence demonstrates another process found in poetry: finding again those psychic objects that have been lost to memory (Clancier, 2001). There is also, in Mr. A's discourse, a broad recourse to themes that are very typical of the haiku form - nature, time, and the awakening of the senses-which confirms the suitability of our choice of poetry. For example: "when my cat just lets go and purrs while sitting on my lap, I can feel that he is happy, secure and well, and then I calm down too. The cat soothes me" and "It's true that the scent of cut grass is spring for me. It smells so good, yes, that's right. And something good I'm thinking about now is when the nightingales start to sing in the evening. They sing and their song is wonderful."

This rich range of themes and the evocative power of haiku in their suggestive brevity invite us to think in new ways about ourselves and our relation to illness and disease.

We believe that this type of creative work can have an influence on how cancer is experienced and represented in the context of palliative care. Poetry-writing workshops based on short, structured forms such as haiku can allow for a fuller discourse about cancer to emerge. This case history is a first step in a larger research program that will include additional studies involving larger numbers of participants in group and individual poetrywriting workshop sessions. Poetry — haiku in particular — can provide clinical psychologists, especially those working in psycho-oncology, with a primary resource in the "work of illness" with patients and may even be a way "to attain the most transcendent heights" (Bacqué, 2013, p. 138). 
Acknowledgements: The authors would like to share their warmest thoughts and appreciation of Mr. A, who has passed away from cancer; his poetic sensibility and acuity brought us much joy.

Declaration on conflict of interest: The authors declare that they have no conflict of interest whatsoever as regards this article.

Translated by John Holland 


\section{APPENDIX A}

\section{HAIKU, TRANSLATED FROM FRENCH INTO ENGLISH}

\begin{tabular}{|c|c|c|c|c|}
\hline Death & Sensations & Time & Love & Spirituality \\
\hline $\begin{array}{c}\text { Beat of butterfly wings } \\
\text { as if in desperation } \\
\text { of this world }\end{array}$ & $\begin{array}{l}\text { Morning in spring - } \\
\text { even my shadow } \\
\text { is brimming with life! }\end{array}$ & $\begin{array}{r}\text { Time which eff } \\
\text { a kiss- } \\
\text { for intens }\end{array}$ & $\begin{array}{l}\text { For that very look } \\
\text { I threw my heart } \\
\text { into all of hell's fires }\end{array}$ & $\begin{array}{l}\text { All in this world } \\
\text { at an inferno's summit } \\
\text { to consider the flowers! }\end{array}$ \\
\hline Kobayashi Issa & Kobayashi Issa & Anonymous & Anonymous & Kobayashi Issa \\
\hline $\begin{array}{l}\text { Hawthorne now in bloom } \\
\text { as a new day is dawning } \\
\text { and I, growing old... }\end{array}$ & $\begin{array}{l}\text { In the young grasses } \\
\text { the elderly swallow } \\
\text { forgets its roots. }\end{array}$ & $\begin{array}{l}\text { A carp jumps - } \\
\text { from the ripples } \\
\text { in the autumn moon }\end{array}$ & $\begin{array}{c}\text { Your arms, I forget } \\
\text { that the world just falls apart } \\
\text { amnesiac love }\end{array}$ & $\begin{array}{c}\text { And so I am here } \\
\text { just where the blue of the sea } \\
\text { is without limit. }\end{array}$ \\
\hline Kirikino & Yos & Masaoka Shiki & Anon & Taneda Santoka \\
\hline $\begin{array}{l}\text { As we grow older- } \\
\text { even the length of the days } \\
\text { is a source of tears }\end{array}$ & $\begin{array}{l}\text { Crossing the wastelands } \\
\text { the high banks of the clouds } \\
\text { weigh down upon me }\end{array}$ & $\begin{array}{l}\text { Our beautiful years } \\
\text { out on the abandoned beach } \\
\text { sunshine in July }\end{array}$ & $\begin{array}{l}\text { Nothing that is mine } \\
\text { except for peace in my heart } \\
\text { and the cool, fresh air }\end{array}$ & $\begin{array}{l}\text { To read in the lake } \\
\text { realities' reflections } \\
\text { ripples on water }\end{array}$ \\
\hline Kobayashi Issa & Yosa Buson & Kirikino & Kobayashi Issa & Kirikino \\
\hline
\end{tabular}




\section{APPENDIX B}

EXAMPLE OF HAIKU WITH FILLED-IN MIDDLE LINE, BY MR. A
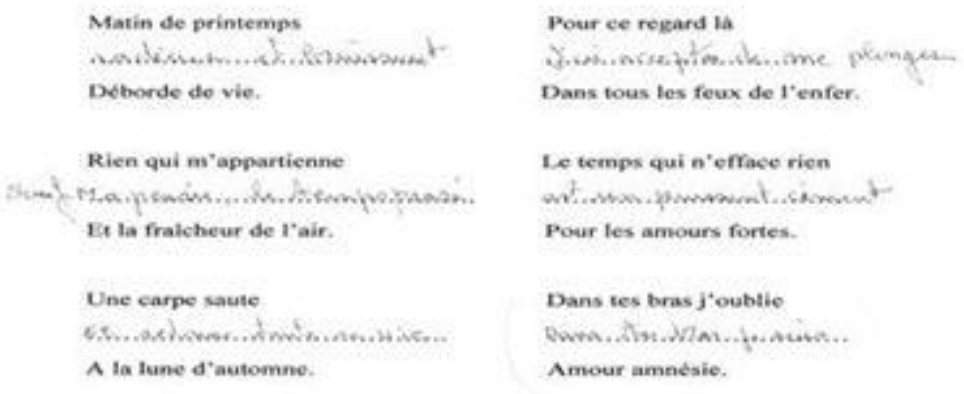


\section{APPENDIX C}

FREE HAIKU, BY MR. A

$$
\begin{aligned}
& \text { L olivios centenaine devant mas. } \\
& \text { selpore ses ramsara it so corleur }
\end{aligned}
$$

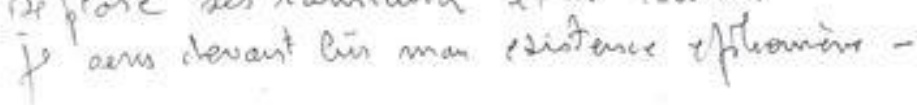

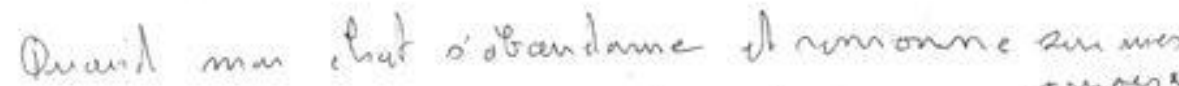

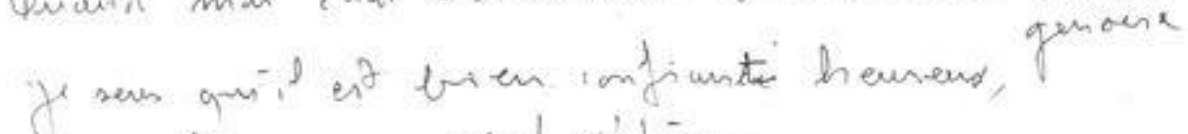

$$
\begin{aligned}
& \text { A min true min esfut sialaise. } \\
& \text { L'odeur des hebes couppes, } \\
& \text { ceat le mintem fo ouñ neverent o }
\end{aligned}
$$

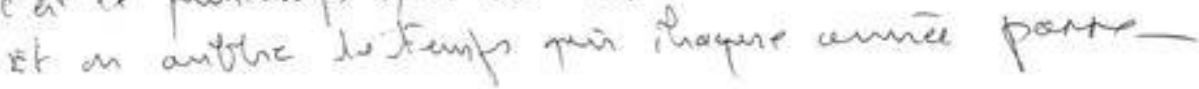




\section{REFERENCES}

Aitken, R. (1978). A Zen Wave: Basho's Haiku and Zen. Berkeley, CA: Weatherhill. Bacqué, M.-F. (2013). Le « travail de la maladie » revisité par la psycho-oncologie [The "work of illness" revised by French psycho-oncologists]. Psycho-Oncologie, 7(3), 137-139. doi:10.1007/s11839-013-0434-2

Blanchet, A. (1991). Dire et faire dire : L'entretien [Speaking and eliciting speech: The interview]. Paris, France: A. Colin.

Blanton, S. (1960). The healing power of poetry. New York, NY: Thomas Crowell.

Bounon, L., \& Lassaunière, J.-M. (1990). Le discours sur la mort et la clinique du réel : desillusions [Discourses on death and the Real in the clinic: Dis-illusions]. Revue JALMALV: Jusqu'à la mort accompagner la vie, (23). Retrieved from http://www.usp-lamirandiere.com/desillus.htm

Cannone, P., Marie, D., \& Dudoit, E. (2008). Sensualité, sexualité et cancer du sein : l'expérience d'ateliers esthétiques [Sensuality, sexuality and breast cancer: experiences in beauty workshops]. In Daniel Serin \& G. de Rauglaudre (Eds.), Cancer du sein avancé (pp. 191-196). Paris, France: Springer.

Clancier, A. (2001). Le travail du poème : Figurabilité et poésie [Poetry work: Poetry and representation]. Revue française de psychanalyse, 65(4), 1283-1290. doi:10.3917/rfp.654.1283

Collins, K. S., Furman, R., \& Langer, C. L. (2006). Poetry therapy as a tool of cognitively based practice. The Arts in Psychotherapy, 33(3), 180-187. doi:10.1016/j.aip.2005.11.002

Gergen, K. J. (2000). Die poetische dimension: Therapeutische möglichkeiten [The poetic dimension: Therapeutic options]. In K. G. Deissler \& S. McNamee (Eds.), Phil und Sophie im Dialog Die soziale Poesie therapeutischer Gespräche (pp. 97-108). Heidelberg, Germany: Carl-Auer Verlag.

Gibbs, R. J. (1994). The poetics of mind. Cambridge, England: Cambridge University Press. 
Houlding, S., \& Holland, P. (1988). Contributions of a poetry writing group to the treatment of severely disturbed psychiatric inpatients. Clinical Social Work Journal, 16(2), 194 200. doi:10.1007/BF00754450

Irubetagoyena, J. (2010, August 10). Haïkus de Kirikino | Kirikino Ilargian. Retrieved from http://www.kirikino.biz/Kirikino-Ilargian/Haikus-de-Kirikino/

Jasen, P. (2009). From the "silent killer" to the "whispering disease": Ovarian cancer and the uses of metaphor. Medical History, 53(4), 489-512. doi:10.1017/S0025727300000521

Lakoff, G., \& Johnson, M. (1980). Metaphors we live by. Chicago, IL: Chicago University Press.

Lakoff, G., \& Johnson, M. (1999). Philosophy in the flesh. New York, NY: Basic Books.

Lakoff, G., \& Turner, M. (1989). More than cool reason: A field guide to poetic metaphor. Chicago, IL: University of Chicago Press.

Langosch, D. S. (1987). The use of poetry therapy with emotionally disturbed children. The American Journal of Social Psychiatry, 7(2), 97-100.

Leedy, J. J. (1969). Poetry therapy: The use of poetry in the treatment of emotional disorders. Philadelphia, PA: Lippincott.

Marchand, G. (2014, August 6). Un haiku. Retrieved from http://www.unhaiku.com/

Maslow, A. (1943). A theory of human motivation. Psychological Review, 50, 370-396. doi:10.1037/h0054346

Maslow, A. (1962). Toward a psychology of being. New York, NY: J. Wiley \& Sons.

Mazza, N. (1996). Poetry therapy: A framework and synthesis of techniques for family social work. Journal of Family Social Work, 1(3), 3-18. doi:10.1300/J039v01n03_02

Mazza, N. (1999). Poetry therapy: Interface of the arts and psychology. Boca Raton, FL: CRC Press.

McLoughlin, D. (2000). Transition, transformation, and the art of losing: Some uses of poetry in hospice care for the terminally ill. Psychodynamic Counseling, 6(2), 215-234. doi:10.1080/135333300407558 
Menzel, R. (1954). Contre le cancer : recherches et découvertes des savants dans le monde entier [Countering cancer: Worldwide scientific research and discoveries]. (A. Henry, Trans.). Paris, France: Éditions Pierre Horay. (Original work published 1953).

Molette, P., \& Landré, A. (2014). Tropes (Version VF 8.4). [Software]. Available from http://www.tropes.fr/download.htm.

Moysan, S. (2012, September 15). Les maîtres du Haiku |Éternels Éclairs. Retrieved from http://www.eternels-eclairs.fr/haikus-basho-buson-issa-shiki-santoka.php

Murphy, G. L. (1996). On metaphoric representation. Cognition, 60(2), 173-204. doi:10.1016/0010-0277(96)00711-1

Pedinielli, J.-L. (1993). Psychopathologie du somatique : La "maladie-du-malade" [Somatic psychopathology: The "illness-of-the-ill”]. Cliniques méditerranéennes, 37/38, 121137.

Pedinielli, J.-L. (1999). Les théories personnelles des patients [Patients' personal theories]. Pratiques Psychologiques, 4, 53-62.

Pollack, A. E., \& Korol, D. L. (2013). The use of haiku to convey complex concepts in neuroscience. JUNE: Journal of Undergraduate Neuroscience Education, 12(1), A42-A48.

Prescott, F. C. (1922). The poetic mind. New York, NY: Macmillan.

Reiter, S. (1997). Poetry therapy: Testimony on Capitol Hill. Journal of Poetry Therapy, 10(3), 169-178.

Ricœur, P. (1982). Imagination et métaphore [Imagination and metaphor]. Psychologie Medicale, 14(12), 1883-1887.

Santarpia, A., Blanchet, A., Venturini, R., Cavallo, M., \& Reynaud, S. (2006). La catégorisation des métaphores conceptuelles du corps [Categorization of conceptual metaphors of the body]. Annales Médico-psychologiques, revue psychiatrique, 164(6), 476-485. doi:10.1016/j.amp.2005.01.008

Santarpia, A., Tellène, J., \& Carrier, M. (2013). Les effets d'un protocole d'écriture poétique SANTEL sur l'image érotique du corps dans le traitement du cancer féminin : étude pilote [The effects of poetry-writing SANTEL on erotic body image in remission of 
cancer in women: A pilot study]. Psycho-Oncologie, 7(3), 156-162. doi:10.1007/s11839-013-0426-2

Santarpia, A., Venturini, R., Blanchet, A., \& Cavallo, M. (2012). Metaphorical conceptualizations of the body in psychopathology and poetry. DELTA: Documentação de estudos em lingüística teórica e aplicada, (26), 1-17. doi:10.1590/S0102-44502010000300003

Semino, E., Demjen, Z., \& Koller, V. (2014). "Good" and "bad" deaths: Narratives and professional identities in interviews with hospice managers. Discourse Studies, 16(5), 667-685. doi:10.1177/1461445614538566

Shelton, D. L. (1999). Healing words. American Medical News. Retrieved from http://web.archive.org/web/20030802160400/http://www.ama-assn.org/scipubs/amnews/pick_99/feat0517.htm

Shrodes, C. (1949). Bibliotherapy: A theoretical and clinical experimental study (Unpublished doctoral dissertation). University of California, Berkeley, CA.

Southall, D. (2013). The patient's use of metaphor within a palliative care setting: Theory, function and efficacy. A narrative literature review. Palliative Medicine, 27(4), 304313. doi: $10.1177 / 0269216312451948$

Stolberg, M. (2014). Metaphors and images of cancer in Early Modern Europe. Bulletin of the History of Medicine, 88, 48-74. doi:10.1353/bhm.2014.0014

Turner, M. (1998). The literary mind: The origins of thought and language. New York, NY: Oxford University Press. 